\title{
Secondary disturbances of low and moderate severity drive the dynamics of eastern Canadian boreal old-growth forests
}

\author{
Maxence Martin ${ }^{1,2}\left(\right.$ D $\cdot$ Hubert Morin ${ }^{1,2} \cdot$ Nicole J. Fenton ${ }^{2,3}$
}

Received: 21 January 2019 / Accepted: 1 October 2019/Published online: 11 December 2019

(C) INRA and Springer-Verlag France SAS, part of Springer Nature 2019

\begin{abstract}
- Key message Both low- and moderate-severity secondary disturbances are drivers of eastern Canadian boreal oldgrowth forests dynamics. Moderate-severity disturbances reflect mainly spruce budworm outbreaks. Low-severity disturbances are produced by both spruce budworm outbreaks and random events such as windthrow. Each level of disturbance severity has a specific impact on stand dynamics, and both shape the diversity of boreal old-growth forests. - Context A regular succession of low-severity disturbances is seen as determining the dynamics of the old-growth stage (gap dynamics); however, recent studies suggest that moderate-severity secondary disturbances also play an important role in the dynamics of eastern Canadian boreal forests.

- Aims This study aims to determine if eastern Canadian boreal old-growth forests are driven by a combination of low- and moderate-severity secondary disturbances.

- Methods We reconstructed the 200-year disturbance history of 20 boreal old-growth stands using dendrochronological analysis. We discriminated low- from moderate-severity disturbances based on their respective influence on mean stand growth.

- Results The secondary disturbance regime of eastern Canadian boreal old-growth forests varies highly over time, reflected by disturbance peaks in the chronological record. Most peaks occurred during spruce budworm outbreaks related to both low- and moderate-severity disturbances. Between each peak, low-severity disturbances dominate. Each level of disturbance severity has specific consequences for stand dynamics.

- Conclusion Both low and moderate secondary disturbances are drivers of forest dynamics in eastern Canadian boreal oldgrowth stands and shape the structural diversity of these stands. The complexity of these dynamics should be recognized in management planning to ensure the efficiency of old-growth forest conservation policies.
\end{abstract}

Keywords Low severity $\cdot$ Moderate severity $\cdot$ Natural disturbance $\cdot$ Succession $\cdot$ Spruce budworm $\cdot$ Windthrow

Handling Editor: Andreas Bolte

Contribution of the co-authors Maxence Martin designed the experiment, carried out the field work and the data preparation, analyzed the data, and wrote the manuscript. Hubert Morin supervised the field work, the data preparation, the analyses, and the manuscript writing. Nicole Fenton supervised the field work, the data preparation, the analyses, and the manuscript writing and checked the English language during the manuscript writing.

\section{Maxence Martin}

maxence.martin1@uqac.ca

1 Département des Sciences Fondamentales, Université du Québec à Chicoutimi, 555 boul. de l'Université, Chicoutimi, G7H2B1 QC, Canada
2 Centre d'Étude de la Forêt, Université du Québec à Montréal, P.O. Box 8888, Centre-ville Station, Montréal, QC H3C 3P8, Canada

3 Institut de Recherche sur les Forêts, Université du Québec en Abitibi-Témiscamingue, 445 boul. de l'Université, Rouyn-Noranda, QC J9X 5E4, Canada 


\section{Introduction}

Recognition of the prominence of boreal old-growth stands, here defined as stands driven by gap dynamics, represented a major paradigm shift in boreal forest ecology (Kneeshaw and Gauthier 2003; Kuuluvainen 2009). Prior to this shift, the assumptions held that old-growth forests were almost absent in boreal landscapes because of relatively frequent forest fires and that some boreal forest stands did not remain stable in an old-growth phase, but they rather became open peatlands in the absence of fire (Bergeron and Harper 2009; Wirth and Lichstein 2009). Nonetheless, old-growth forests are abundant in the boreal landscape, even in territories where the fire cycle is relatively short; this pattern reflects the random distribution of fires across all age classes (Bergeron et al. 2001). In addition, the distinctive structural attributes and ecological continuity of old-growth stands imply the presence of specific habitats that are absent from younger stands (Fenton and Bergeron 2008; Boudreault et al. 2018). For these reasons, boreal old-growth forests are now recognized as key components of boreal landscapes.

Since the mid-twentieth century, intensive industrial forest harvesting has expanded markedly across the boreal landscape. In territories that are characterized by severe crown fires, such as the boreal forests in eastern Canada, the harvested surface area can approximate $75 \%$ of the burned surface area during the same period (Bouchard and Pothier 2011; Boucher et al. 2017). Furthermore, in landscapes driven by low-severity surface fires and where fire mitigation is very efficient, logging has almost become the only type of severe-intensity disturbance (Östlund et al. 1997). Clearcutting systems are by far the most common harvesting method in the boreal forest biome. This approach is most profitable for forest companies, and the effects of clearcutting are assumed to be equivalent to those from fire (Bergeron et al. 2001). However, fire burns trees of all age classes, while logging primarily affects mature and old forests, thereby rejuvenating the landscape (Östlund et al. 1997; Fall et al. 2004; Bergeron et al. 2006). In addition, the short-term rotation of clearcutting systems accelerates this rejuvenation by inhibiting the establishment of new mature or old stands (Bergeron et al. 2002; Kuuluvainen 2009). The result is a markedly diminished abundance of boreal old-growth forests in managed territories over the last century. The consequential environmental effects include a decline of floral, faunal, and fungal forest species associated with abundant dead wood of diverse decay stages (Siitonen 2001).

Alternative management models have emerged over the two last decades to counter the loss of old-growth stands in managed landscapes. These new approaches copy the natural disturbance regimes of the different managed regions (Kuuluvainen 2002; De Grandpré et al. 2009) or imitate stand-scale natural processes (Vanha-Majamaa et al. 2007; Kuuluvainen 2009). The efficacy of these models, however, depends of an accurate understanding of disturbance regimes in a given area; however, each boreal region differs in terms of climatic factors, disturbance dynamics, and species' traits (Kneeshaw et al. 2011; Shorohova et al. 2011). As such, local-scale studies are necessary to assess whether a particular management strategy is or can be adapted to the local characteristics of a landscape.

The main drivers of secondary disturbance in eastern Canadian boreal forests are spruce budworm (SBWChoristoneura fumiferana (Clem.)) outbreaks and windthrow events (Bouchard et al. 2006; Kerharo 2013; De Grandpré et al. 2018). Other disturbances that drive mortality in these forests include jack pine budworm (Choristoneura pinus pinus) and forest tent caterpillar (Malacosoma disstria) (Jan and Volney 1988; Bergeron and Charron 1994). However, as the main boreal hosts of these two defoliating insects are pioneer species (Nealis and Lomic 1994; Cooke and Lorenzetti 2006), their influence on old-growth dynamics is negligible.

The disturbance regimes of Fennoscandian boreal forests are relatively well understood and involve a mix of low-, moderate-, and high-severity disturbances (Kuuluvainen and Aakala 2011). In contrast, the perception of dynamics within eastern Canadian boreal forests remains relatively simplistic, dividing the disturbance regime into low-severity secondary disturbances and highseverity primary disturbances (Bergeron and Harper 2009; Shorohova et al. 2011). Nonetheless, previous studies have highlighted that secondary disturbance dynamics in regional boreal old-growth forests vary in their severity, nature, and spatial distribution (Kneeshaw and Bergeron 1998; Pham et al. 2004; Aakala et al. 2007). It is likely that disturbances of moderate severity play an important role in the overall landscape disturbance regime, in particular because of the dynamics of the SBW (Kneeshaw et al. 2009; Shorohova et al. 2011).

Similarly, the structural diversity of eastern Canadian boreal forests suggests that these ecosystems are driven by both lowand moderate-severity disturbances (Martin et al. 2018). However, the transition toward an old-growth stage is a progressive process where late-successional species replace progressively the cohort that appeared following the last primary disturbance (Harper et al. 2005; Lecomte et al. 2006; Gauthier et al. 2010). It supposes that disturbances of moderate severity gain progressively in importance at the later stages of the old-growth succession process. Furthermore, differences in the severity of secondary disturbances also imply differences in the post-disturbance regeneration dynamics (Kneeshaw and Bergeron 1998; Montoro Girona et al. 2018). It is therefore likely that the secondary disturbance regime of eastern Canadian boreal forests is more complex than is currently portrayed.

Our study aims to determine if the secondary disturbance regime of eastern Canadian boreal stands is driven by various types of secondary disturbance. We hypothesized that (1) lowand moderate-severity disturbances present different temporal patterns and that (2) moderate-severity disturbances are more abundant in true old-growth stands and favor different components of the regeneration layer. The innovative nature of our 
research lies in using dendrochronological data for analyzing disturbances of low and moderate severity over the two last centuries in forests at different stages of the old-growth succession. Thus, our study is not restricted to the effects of the most recent secondary disturbances, but we will observe their longterm patterns of secondary disturbance and their influence on old-growth stand dynamics. Consequently, our research contributes to the increasing body of literature discussing the complexity of secondary disturbance regimes in boreal landscapes by reconstructing the disturbance history of eastern Canadian boreal old-growth forests.

\section{Methods}

\subsection{Study area}

The study was conducted in a $2200-\mathrm{km}^{2}$ area of public lands, located south-east of Lake Mistassini, Quebec ( $72^{\circ} 52^{\prime} 36^{\prime \prime} \mathrm{W}$, $50^{\circ} 18^{\prime} 50^{\prime \prime} \mathrm{N}$ ) (Fig. 1). This area lies within the black spruce (Picea mariana (Mill.))-feather moss bioclimatic domain, the dominant boreal forest domain in eastern Canada. Regional topography is characterized by gentle hills having an altitude ranging from 350 to $750 \mathrm{~m}$ asl. Thick glacial till dominates the surficial deposits, and sand deposits or vast bogs often surround waterways. Mean annual temperature ranges from -2.5 to $0.0^{\circ} \mathrm{C}$, annual rainfall (rain and snow) is $900-1100 \mathrm{~mm}$, and the growing season lasts 140-150 days (Robitaille and Saucier 1998). Black spruce and balsam fir (Abies balsamea (L.) Mill.) are the dominant tree species. We selected this study area as it encompasses the environmental diversity of the black spruce-feather moss bioclimatic domain, from poorly drained valley bottoms situated on organic deposits to well-drained till slopes. We also selected this area as timber exploitation began in 1991, initially at low levels until 2000 when harvest levels increased. Consequently, oldgrowth stands remain abundant and relatively accessible.

\subsection{Sampling and data preparation}

Based on the nomenclature of the Quebec Ministry of Forests, Wildlife, and Parks (MFWP), the study area is divided into 19 environmental forest types. Six of these, however, cover $72 \%$ of the forest area. Given the environmental diversity of the study area, we focused our sampling within these six environmental forest types. Moreover, to encompass the complete old-growth successional sequence, we aimed to have an equal representation

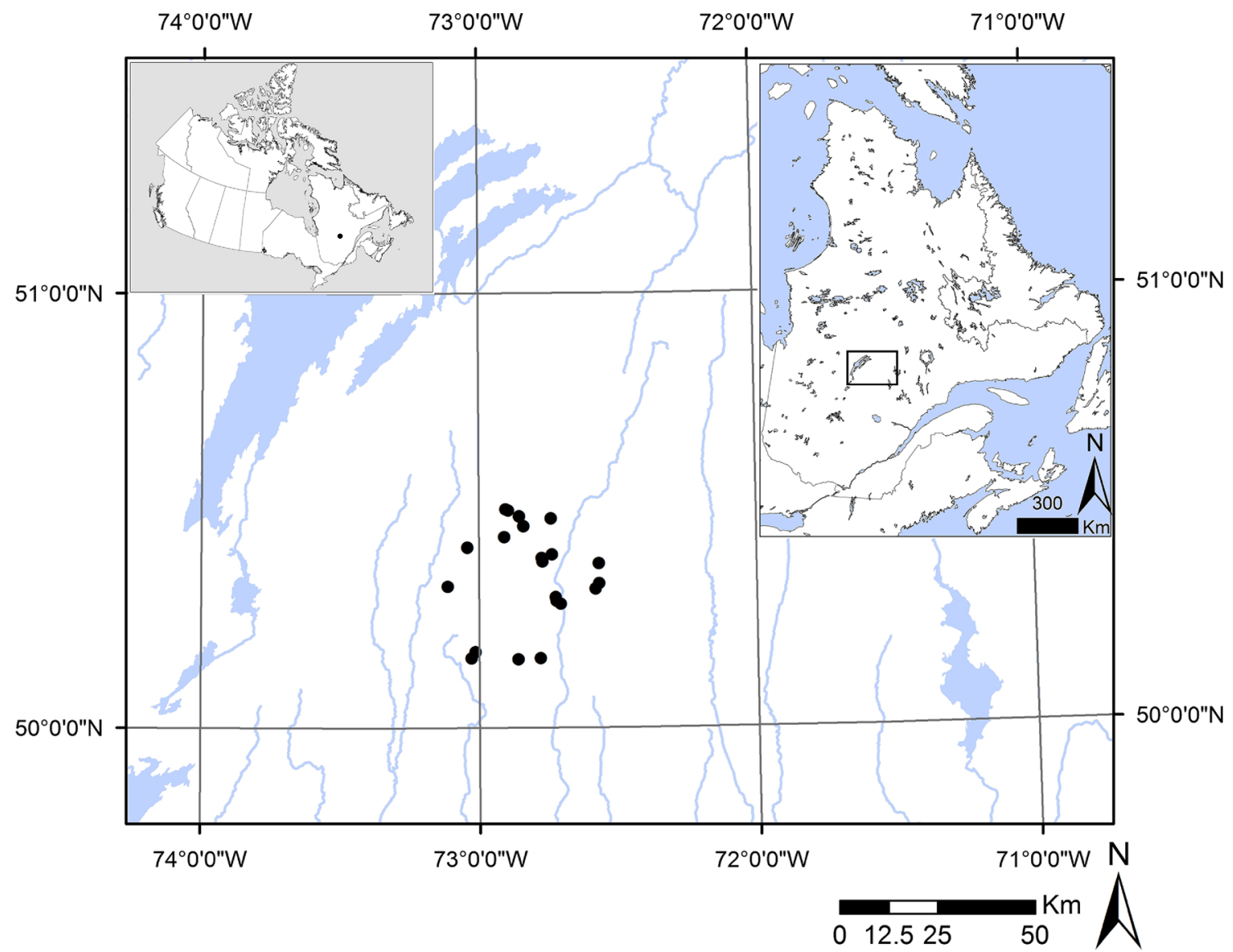

Fig. 1 Map of the study area. Black dots represent the sample sites, and blue lines and polygons represent rivers and standing waterbodies, respectively. The inset maps indicate the position of the study area map in Canada (left) and in the province of Quebec (right) 
of sites belonging to mature, transition old-growth, and true oldgrowth phases. According to the literature for this ecosystem type (Uhlig et al. 2001; Bergeron and Harper 2009; Gauthier et al. 2010), the likely age classes associated with each phase are 80 100 years for even-aged mature stands, 100-200 years for transition old growth, and $>200$ years for true old growth.

We estimated the minimum age of 42 sites in a preliminary survey by sampling two cores at the base of five dominant and codominant trees at each site. Then, we performed a stratified random sampling to sample sites from each environmental type and age class. Twenty-one (21) sites were sampled during the summer and autumn of 2014 and 2015. We inventoried at least one site per environmental type and age class, except for the "Black spruce-feather moss on low slope, till deposit, and subhydric drainage" type, as we did not find a site within the 100-200-year age class (Table 3 in the Appendix).

We sampled coniferous basal discs in the same $20 \times 20-\mathrm{m}$ plots sampled by Martin et al. (2018), with the goal of obtaining 30 living and dead stems having a diameter at breast height (dbh) $\geq 9 \mathrm{~cm}$ (merchantable stems). We kept discs that showed stem decay if the rot was partial and the analysis of most of the tree rings remained possible. When it was impossible to sample a minimum of 30 stems per site, we sampled trees near the plot edge or saplings within the plot, depending on the site characteristics.

Discs were air-dried and mechanically sanded for tree-ring measurements. Then, we measured tree rings along two radii to the nearest $0.01 \mathrm{~mm}$. These ring-width series were corrected by a combination of visual cross-dating and the use of the COFECHA computer program (Holmes 1983). We rejected accurately dated series having a poor statistical fit with the average curve of the disc due to growth anomalies. Similarly, we removed a disc from the final dataset when one of the two series measured on the basal disc correlated poorly with the mean stand chronology. We obtained 1550 accurately dated dendrochronological series, belonging to 775 trees.

\subsection{Data preparation}

We determined the diameter distribution of merchantable stems $(\mathrm{dbh} \geq 9 \mathrm{~cm})$ and saplings (height $\geq 1.3 \mathrm{~m}$ and $\mathrm{a} \mathrm{dbh}<9 \mathrm{~cm})$ in each plot following Martin et al. (2018) and using Weibull's equation (Bailey and Dell 1973). A Weibull's shape parameter (WSP) $\geq 1.5$ indicates a normal diameter distribution, and a WSP $<1.5$ indicates an irregular diameter distribution. We also calculated the cohort basal area proportion (CBAP) for each site using the formula of Kneeshaw and Gauthier (2003):

$C B A P=\frac{\left(\mathrm{BA}_{N+1 \text { trees }}+0.1\right)}{\left(\mathrm{BA}_{N+1} \text { trees }+\mathrm{BA}_{\text {First cohort trees }}+0.1\right)}$

where BA is the basal area. We identified first cohort trees, $N$ +1 trees, and the old-growth stage of each plot following Martin et al. (2018). Stands were defined as even-aged if WSP $\geq 1.5$ and $\mathrm{CBAP}<0.3$, true old-growth when $\mathrm{WSP}<1.5$ and $\mathrm{CBAP}>0.6$, and transition old-growth for all other conditions. We selected this methodology due to the increasing acknowledgment of the complexity of forest succession, including that of boreal forests (Cumming et al. 2000; McCarthy and Weetman 2006; Smirnova et al. 2008). Therefore, combining the CBAP and the WSP improves the discrimination of the different stages of old-growth succession while recognizing both the intrinsic progressive nature of the transition toward the old-growth stage and alternative successional pathways (Table 1). Among the 21 sites sampled, 1 was identified as even-aged, 10 as transition old-growth, and 10 as true old-growth (Table 4 in the Appendix). We therefore removed the even-aged site from further analysis. In addition, the number of trees sampled was almost equivalent between the two old-growth stages for CE 1800-2000 period; however, the number was very low for both old-growth stages prior to CE 1800 . For this reason, analyses focused on the CE 1800-2000 period (Table 5 in the Appendix).

Abrupt and persistent growth changes (\%GC) are an effective proxy for indicating the occurrence of a secondary disturbance and thus override short- and long-term growth patterns associated with climate (Nowacki and Abrams 1997; Fraver and White 2005). We identified these growth changes by comparing sequential 10-year ring widths via the formula of Nowacki and Abrams (1997):

$\% \mathrm{GC}=\left\{\left(M_{2}-M_{1}\right) / M_{1}\right\} \times 100$

where $M_{1}$ is the mean ring width for the first 10-year period, and $M_{2}$ is the mean ring width for the subsequent 10-year period. We classified growth changes by intensity based on the classes defined by Nowacki and Abrams (1997): major (\%GC $\geq 50 \%$ ) and minor (\%GC $=25-50 \%)$. These thresholds are well adapted to boreal forests, where tree growth is generally low (Tremblay et al. 2011). We calculated \%GC for each tree, using the mean value of the two raw ring-width series measured for each tree (tree chronology), and for each species per stand, using the mean value of all raw ring-width series measured for each species in the plot (mean plot chronology). We chose to separate tree species due to the different dynamics and strategies vis-à-vis disturbances for black spruce and balsam fir. Relative to black spruce, balsam fir is more sensitive to SBW outbreaks, windthrow events, and root rot (Basham 1991; Ruel 2000; Morin et al. 2009); however, balsam fir regeneration is more competitive than that of black spruce when a canopy opening occurs following a disturbance (Doucet and Boily 1995; Messier et al. 1999). As a result, the abundance of balsam fir in an eastern Canadian oldgrowth stand may vary markedly over time (Pham et al. 2004; De Grandpré et al. 2009). Therefore, merging the results of both species in mixed stands could have biased the results. We determined growth releases from mean plot chronologies only when 
Table 1 Number of sites $(N)$, mean and standard deviation of the Weibull's shape parameter (WSP), cohort basal area ratio (CBAP), minimum time since last fire (MTSLF), and number of trees sampled ( $B S$ black spruce, $B F$ balsam fir, $J P$ jack pine) per old-growth stage

\begin{tabular}{|c|c|c|c|c|c|c|c|}
\hline \multirow[t]{2}{*}{ Stage } & \multirow[t]{2}{*}{$N$} & \multirow[t]{2}{*}{ WSP } & \multirow[t]{2}{*}{ CBAP } & \multirow[t]{2}{*}{ MTSLF (years) } & \multicolumn{3}{|c|}{ Number of trees sampled } \\
\hline & & & & & $\mathrm{BS}$ & $\mathrm{BF}$ & JP \\
\hline Transition OG & 10 & $1.45 \pm 0.71$ & $0.28 \pm 0.37$ & $176.50 \pm 67.13$ & $35.60 \pm 10.27$ & $1.80 \pm 3.79$ & $0.30 \pm 0.95$ \\
\hline True OG & 10 & $0.87 \pm 0.14$ & $0.84 \pm 0.12$ & $252.50 \pm 35.17$ & $25.30 \pm 9.63$ & $9.60 \pm 9.47$ & $0.00 \pm 0.00$ \\
\hline
\end{tabular}

$O G$ old growth

$\geq 10$ trees constituted the chronology to ensure that the chronologies were representative of the stand's dynamics.

Discriminating low- from moderate-severity disturbances is challenging, as the threshold between the levels of low and moderate is often unclear (Hart and Kleinman 2018). The most common solution is to use size thresholds, either defined arbitrarily or related to stand characteristics (McCarthy 2001; Reyes and Kneeshaw 2008; Hart and Kleinman 2018). However, such methods cannot be used with dendrochronological data, as information related to the disturbances themselves is generally missing. Yet, tree growth releases are reliable indicators of disturbance dynamics and thus for canopy and tree population turnover (Nowacki and Abrams 1997; Szewczyk et al. 2011; Khakimulina et al. 2016); this makes them a relevant proxy for the disturbance regime. To determine the severity of a secondary disturbance, we considered that a low-severity disturbance would induce individual tree growth release but would not influence mean plot growth, i.e., no growth release in the mean plot chronology, as only a small fraction of the trees is disturbed. This scenario implies few changes in the stand canopy and age structure. In contrast, a disturbance of moderate severity will disturb a larger proportion of trees, leading to important changes in stand structure. In turn, this provokes a greater number of growth releases that will influence mean plot growth. As such, we defined low-severity disturbances as disturbances lacking a significant influence on post-disturbance stand growth because of low overstory mortality. Moderate-severity disturbances are disturbances that significantly and positively influence post-disturbance stand growth because of moderate overstory mortality.

To link the two scales (tree and plot) and determine if each release observed between CE 1800 and 2000 on an individual tree was part of a secondary disturbance of low or moderate severity, we compared the occurrence of tree growth releases to releases of the corresponding stand and species. We used stand growth release-identified on the mean plot chronologies - to define windows within which individual tree growth release could be considered as resulting from a moderate-severity disturbance. For a given stand, all individual tree growth releases that occurred in the 9 years before or the 9 years after an observed stand growth release were classified as moderate-severity secondary disturbance releases, i.e., the individual tree releases contributed to growth release at the plot scale. If not, they were classified as low-severity secondary disturbance releases, i.e., the individual tree releases did not contribute to any growth change at the plot scale. We selected a 9-year threshold as Nowacki and Abrams (1997) applied a 10-year window to identify growth releases. Hence, all individual tree growth releases that occurred 9 years before or after a stand growth release may have contributed to this release. As such, our methodology accounts for potential lags that can be observed between disturbance and growth releases, as well as lags between disturbance and tree mortality (Worrall et al. 2005; De Grandpré et al. 2018). To distinguish between strong juvenile growth after a primary disturbance and growth release due to low- or moderate-severity secondary disturbance, we only considered growth releases that occurred 40 years after the minimal year of stand establishment. This 40-year threshold corresponds to the end of the marked juvenile post-fire recruitment period in even-aged stands (Rossi et al. 2009) as well as the beginning of gap dynamics under particular conditions (Cumming et al. 2000). Finally, we only retained growth releases for each site and year when the number of trees sampled was $\geq 10$, i.e., we did not determine stand growth release when this condition was not fulfilled.

\subsection{Statistical analysis}

To test our first hypothesis - that low- and moderate-severity secondary disturbances differ in their temporal patterns - we identified for each site and each year the percentage of trees being in a state of growth release and the severity of the secondary disturbance (low or moderate). This method provides an improved description of the stand dynamics to using only the absolute number of trees. Tree and sapling density in eastern Canadian old-growth boreal forests may vary markedly between stands, independent of old-growth stage (Martin et al. 2018). In contrast, the frequency of trees in growth release puts into perspective results extracted from the dendrochronological series at the stand scale, and it is therefore a more suitable descriptor. We then applied a locally weighted regression scatterplot (loess) smoothing with a 10\% span (Trexler and Travis 1993) for various classes of secondary disturbance severity-low and moderate severity combined, low severity only, and moderate severity only- to observe the presence of release peaks and their cooccurrence between stands. By smoothing the annually observed growth releases for all stands, we expect that this methodology will neutralize potential lags in growth releases that can be 
observed from one stand to another following a single disturbance event. In addition, we compared the occurrence of these peaks with the chronologies of Morin and Laprise (1990) and Krause (1997), who identified the SBW outbreaks over the last three centuries at sites near our study area. We considered that the occurrence of a release peak during a SBW outbreak period implied that this insect was the main disturbance agent explaining this peak.

For testing our second hypothesis - that low- and moderateseverity secondary disturbances have different effects on the subsequent stand dynamics - we first used logistic regression to compare stand, tree, and release characteristics related to each identified tree growth release for the transition and true oldgrowth stands. Secondary disturbance severity (low/moderate) was the binary dependent variable, and the following parameters were the independent variables: release intensity (minor/major), old-growth stage (transition/true old growth), species, and diameter class at release. We applied a likelihood ratio test and residual equidispersion to assess model validity. In addition, we checked model predictive ability using the area under the receiveroperating characteristic curve (AUC) method (Zweig and Campbell 1993) and Tjur's coefficient of discrimination (COD; Tjur (2009)). An AUC value $>0.7$ and a COD $>0.2$ represent an excellent predictive ability. In addition, we determined for each disturbance severity the mean percentage of trees presenting growth releases per decade and per site to observe the variation in disturbance history and severity between the study sites. We compared these values by combining old-growth stage and release type using a Kruskall-Wallis test followed by a pairwise Wilcoxon test.

We used R software, version 3.3.1 (R Core Team 2016) for all statistical analyses, running the ROCR (Sing et al. 2005), DescTools (Signorell 2017), and ggplot2 (Wickham 2016) packages. We selected a threshold of $p<0.05$ to establish significance.

\section{Results}

\subsection{Temporal pattern of low- and moderate-severity secondary disturbances}

Considering low- and moderate-severity disturbances together during the CE 1800-2000 period, the proportion of trees having growth releases in the studied stands varies greatly from year to year; nonetheless, eight peaks emerge (Fig. 2). Six of these peaks occurred during SBW epidemics. In addition, there is no period where tree growth releases are absent, except in the oldest portion of the chronology; therefore, secondary disturbances of variable severity represent a continuous element in the studied old-growth stands over the two last centuries.

Relative to the moderate-severity disturbances, the tree growth releases linked to low-severity disturbances vary much less from year to year. Nevertheless, we still observe the eight previously identified peaks, although they tend to be less pronounced. In contrast, the percentage of trees having growth release related to disturbances of moderate severity varies widely over time; this relative abundance alternates between periods where this proportion is equal or greater to the proportion of trees with growth release resulting from low-severity disturbance and periods where the proportion is near zero.

The relative contribution of secondary disturbances of low and moderate severity to the disturbance peaks varies between peaks. Moderate-severity disturbances contributed to six of the eight identified peaks (peaks 1, 2, 3, 5, 6, 8); five occur during SBW outbreaks. The contribution from moderate-severity disturbances is generally equal to that of low-severity disturbances, except for peaks 2 and 6 , where moderate-severity disturbances contribute much more. In contrast, peaks 4 and 7 are due solely to low-severity disturbances and occur outside periods of SBW outbreaks. Therefore, both low- and moderate-severity disturbances drive the secondary disturbance regime of boreal old-

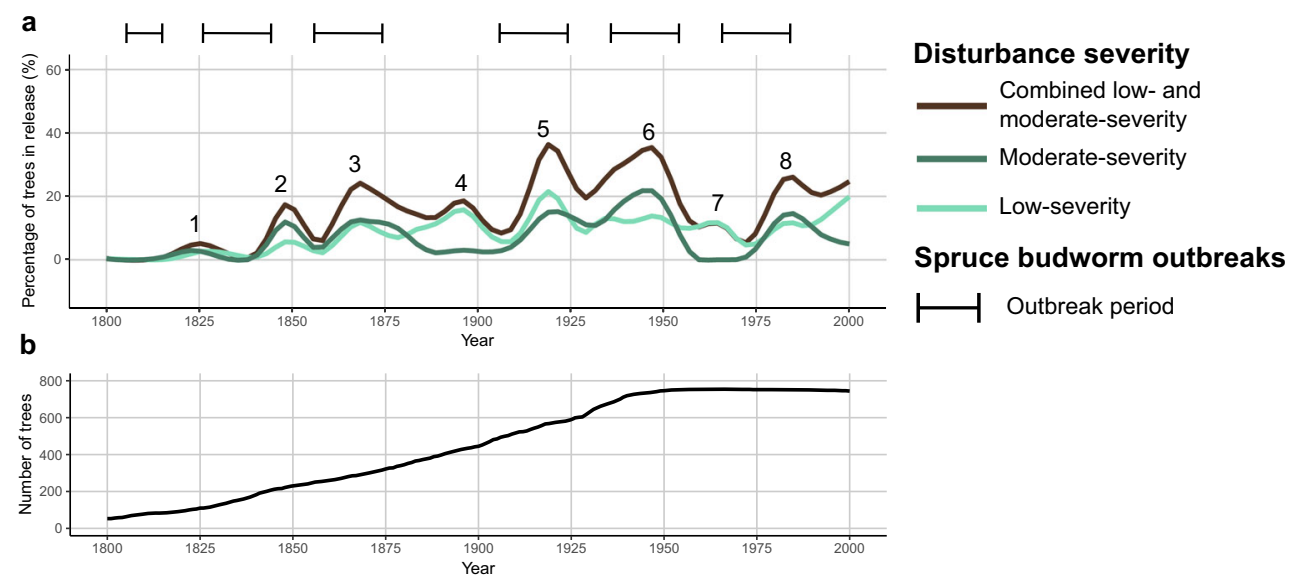

Fig. 2 a Loess smoothing of the percentage of trees having growth release events per decade grouped by secondary disturbance severity: combined low and moderate severity (brown curve), moderate severity (dark green curve), and low severity (light green curve). Numbers identify the eight peaks, and hooks indicate spruce budworm outbreaks. Spruce budworm outbreaks are based on Morin and Laprise (1990) and Krause (1997). b Number of trees that make up the developed tree-ring chronology for the period CE 1800-2000 
growth forests; however, given as they often overlap, the implication is that both can result from the same disturbance agents.

\subsection{Dynamics of old-growth stages}

The four parameters analyzed via logistic regression-oldgrowth stage, release intensity, tree species, and diameter class at release - differed significantly between the levels of disturbance severity (Table 2). The logistic regression model presents an excellent predictive value, as evidenced by the significant loglikelihood test $(p<0.001)$, the strong AUC value $(0.76)$, and the high COD (0.2). For both levels of disturbance severity, trees that show growth releases are mainly small (tree diameter at the moment of release $<10 \mathrm{~cm}$ ) (Fig. 3). Despite their small size, most trees having a diameter at release of $<10 \mathrm{~cm}$ are old ( $>50$ years, Table 6 in the Appendix). Thus, most of the observed releases are due to suppressed trees that benefit from an opening of the canopy. Yet, these trees were generally smaller and younger in moderate-severity disturbances than in low-severity disturbances. Furthermore, the frequency of release observed for balsam fir is higher in moderate- than in low-severity disturbances, even if black spruce is the dominant species for both disturbance severity. Similarly, the frequency of major growth release is higher in moderate- than in low-severity disturbances; however, minor releases are the dominant release type for both types of disturbance. Therefore, the characteristics of the gap fillers differ depending on disturbance severity. The distribution of growth releases resulting from low- and moderate-severity disturbances also varies between the different old-growth stages.

The mean decadal percentage of trees having growth releases due to low-severity disturbances did not differ between oldgrowth stages, but there were fewer trees showing a growth release from moderate-severity disturbances in the transition old growth than in true old growth (Fig. 4). Interestingly, in true old growth, the mean decadal percentage of trees having lowseverity disturbance-induced growth release was similar to that of trees having moderate-severity disturbance-induced growth release. Therefore, the dynamics due to disturbances low severity are similar between the transition and true old-growth forests. Furthermore, stand dynamics related to disturbances of moderate severity are at a similar level to that of low-severity disturbances in true old-growth forests. Consequently, the balance between low- and moderate-severity disturbances changed with the disappearance of the first cohort.

\section{Discussion}

In eastern Canada, both low- and moderate-severity secondary disturbances drive the dynamics within boreal old-growth forests; however, the disturbances occur in both analogous and nonanalogous temporal patterns. Secondary disturbances occur continuously across the landscape. Their severity, however, is not constant over time; severity increased during eight distinct peaks over the last 200 years. Six of these eight peaks coincided with SBW outbreaks. Low- and moderate-severity disturbances also influence gap-filler characteristics, e.g., species and age, and vary between the different old-growth stages.

\subsection{Mixed-severity secondary disturbances drive the dynamics of boreal old-growth forests}

We found that in addition to low-severity disturbances, moderate-severity disturbances are a distinct component of boreal old-growth forests dynamics in eastern Canada, as hypothesized by Shorohova et al. (2011) and Martin et al. (2018). Our results add to the literature highlighting the dynamism of boreal old-growth forests in this region (Kneeshaw and Bergeron 1998; Pham et al. 2004; Aakala et al. 2007) and underline that boreal old-growth forests are not declining ecosystems but rather remain productive and dynamic over centuries in the absence of primary disturbance (Garet et al. 2009; Pollock and Payette 2010; Ward et al. 2014). This dynamism is driven by recurrent mortality events. Our study therefore underlines the long-term resistance and resilience of these ecosystems (sensu Perry and Amaranthus (1997) given that most of the studied stands experienced secondary disturbances of varying severity over the past two centuries. The percentage of trees that experienced growth release was, however, lower in the nineteenth century relative to the twentieth century. Black spruce and balsam fir longevity is relatively low (often $<200$ years), and slow-growing trees tend to live longer than fast-growing ones (Laberge et al. 2000; Larson 2001). It is therefore likely that only a small fraction of the trees that benefited from nineteenth-century disturbances survived until the present. Nevertheless, the release patterns for both disturbance types

Table 2 Results of the logistic regression model comparing the characteristics of the growth releases according to the disturbance severity

\begin{tabular}{|c|c|c|c|c|c|c|c|c|c|c|c|c|c|}
\hline Resid. $d f$ & Resid. dev. & $d f$ & Deviance & $\operatorname{Pr}(>\mathrm{Chi})$ & AIC & AUC & COD & Parameter & $d f$ & Deviance & Resid. $d f$ & Resid. dev. & $\operatorname{Pr}(>\mathrm{Chi})$ \\
\hline \multirow[t]{4}{*}{1612} & \multirow[t]{4}{*}{2110.6} & \multirow[t]{4}{*}{-6} & \multirow[t]{4}{*}{-340.69} & \multirow[t]{4}{*}{$<0.001$} & \multirow[t]{4}{*}{1783.9} & \multirow[t]{4}{*}{0.76} & \multirow[t]{4}{*}{0.2} & Old-growth stage & 1 & 233.232 & 1611 & 1877.3 & $<0.001$ \\
\hline & & & & & & & & Species & 1 & 10.666 & 1610 & 1866.7 & $<0.01$ \\
\hline & & & & & & & & Release intensity & 1 & 69.162 & 1609 & 1797.5 & $<0.001$ \\
\hline & & & & & & & & Diameter class at release & 3 & 27.627 & 1606 & 1769.9 & $<0.001$ \\
\hline
\end{tabular}

AIC Akaike information criterion, $A U C$ area under the receiver-operating characteristics curve, $C O D$ Tjur's coefficient of discrimination 

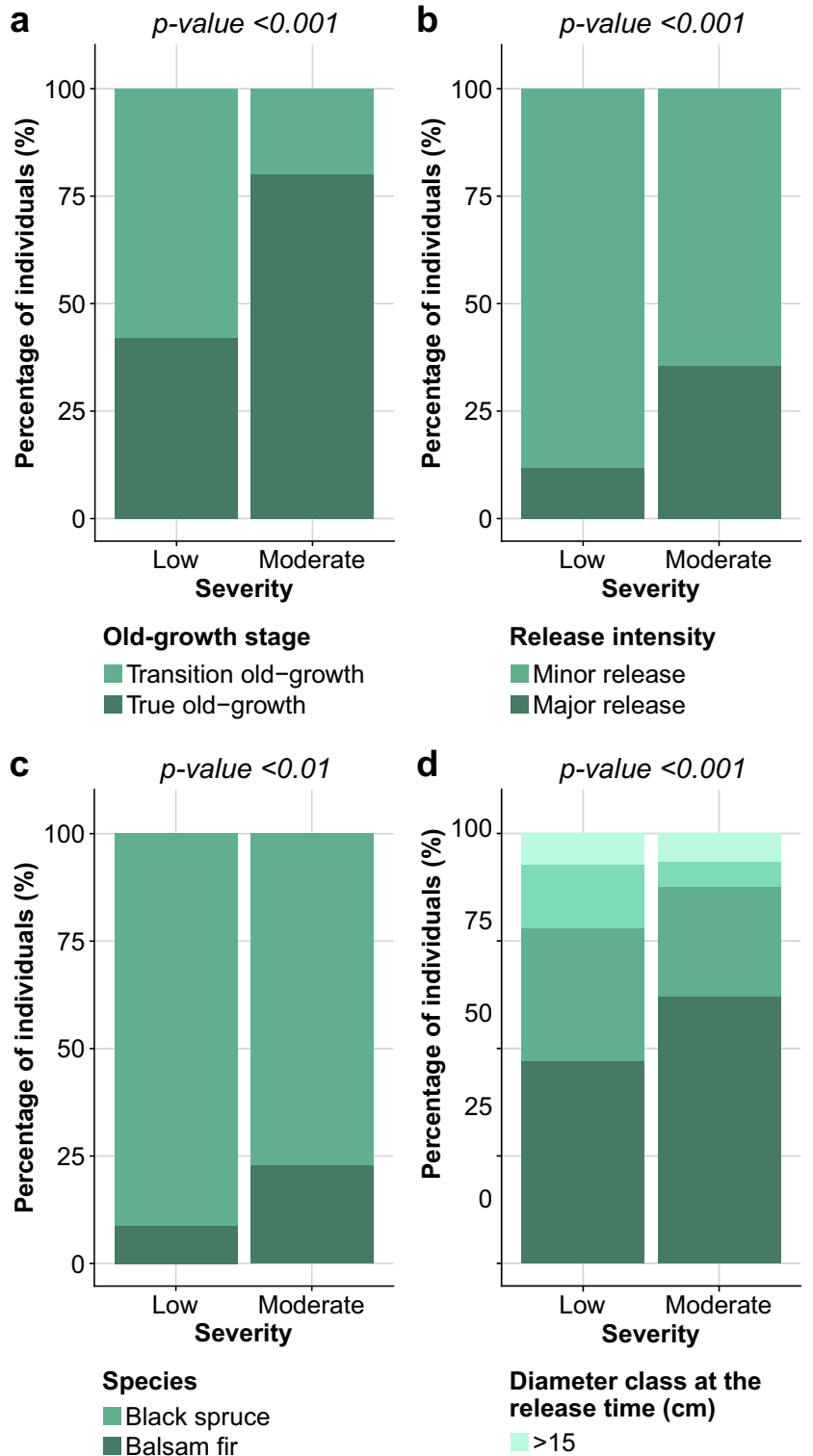

Balsam fir
Release intensity

Minor release

Major release

Diameter class at the release time $(\mathrm{cm})$

$>15$

$10-15$

$5-10$

$\square<5$

Fig. 3 Class distribution and $p$ values of the four parameters analyzed in the logistic regression as a function of the severity of secondary disturbance (low or moderate): a old-growth stage, $\mathbf{b}$ release intensity, $\mathbf{c}$ species, and $\mathbf{d}$ diameter class at release. The $p$ values above each bar represent the significance of the specific parameter based on the logistic regression model (see Table 2)

were similar throughout both centuries. This similarity implies that the studied stands were driven by comparable disturbance dynamics during the CE 1800-2000 period, although these dynamics were less obvious in the nineteenth century.

Moderate-severity disturbances occurred mainly during previously identified SBW outbreaks in the southern portion of the region (Morin and Laprise 1990; Krause 1997). In the eastern Canadian boreal forest, SBW is the main agent of secondary disturbance (Morin et al. 2009; Shorohova et al. 2011). Previous studies have demonstrated the importance of SBW

outbreaks for the dynamics of boreal old-growth forests situated in the main SBW distribution range (Kneeshaw and Bergeron 1998; Pham et al. 2004; Aakala et al. 2007). However, our study sites are currently at the northern edge of SBW distribution; thus, SBW outbreaks should have a limited influence on the disturbance regime of our study stands (Gray 2008). Recent reconstructions of the spatial patterns of SBW outbreaks in Quebec over the twentieth century (Navarro et al. 2018) also indicate that our study stands lie outside of SBW hotspots. Nonetheless, we observed a strong influence of this disturbance agent over the two last centuries within our study area; this observation highlights the importance of SBW in landscape dynamics, even at the northern limit of its normal range. SBW outbreaks are cyclical events having a 30-year periodicity (Morin et al. 2009). Moderateseverity disturbances from SBW outbreaks follow the same temporal cycle. Furthermore, mortality caused by SBW is highly variable between stands during an outbreak; the effects vary from a moderate thinning of suppressed trees to a significant mortality of canopy trees (Lesieur et al. 2002; Kneeshaw et al. 2009; Morin et al. 2009). Similarly, the identified SBW outbreak peaks in our study provoked disturbances of both low and moderate severity, indicating differences in mortality between stands during a single outbreak. This complex pattern of disturbance may also be explained by our study stands being at the northern range of SBW distribution, thereby resulting in SBW-related damage to be more limited relative to areas further south (Bergeron and Charron 1994; MacLean and Andersen 2008; Kneeshaw et al. 2009). Thus, SBW is an important driver of the secondary disturbance regime in our study area; its influence is cyclical and varies in severity between stands and during a SBW outbreak.

Secondary disturbances of low severity occurred almost continuously throughout our 200-year chronology. This pattern contrasts with that of secondary disturbances of moderate severity that occurred more sporadically. This continuous low-severity disturbance implies a background mortality throughout the study area. The causes of this background mortality include windthrow and fungal rot, but these events occur more randomly and cause a lower degree of mortality at the landscape scale than do SBW outbreaks (Kerharo 2013; Waldron et al. 2013; Girard et al. 2014). However, two of the eight identified peaks occurred outside SBW outbreaks and were dominated by low-severity disturbances. It is possible that these two peaks resulted from particular climatic events that caused simultaneous low-severity windthrow events across the landscape. In eastern Canadian boreal forests, the secondary disturbance regime is a complex process that comprises a constant background mortality punctuated by moderateseverity disturbances.

\subsection{Influence of the mixed-severity secondary disturbance regime on forest structure and succession}

We observed moderate-severity disturbances mainly in true old-growth stands, and these disturbances favored smaller 
Fig. 4 Box plot of the stand mean decadal percentage of trees experiencing growth release based on old-growth stage and disturbance severity. Diamonds represent mean values and letters identify significant differences

Fig. 5 Conceptual model of the theoretical dynamics of boreal old-growth forests under a disturbance regime that combines low-, moderate-, and highseverity disturbances. Boxes represent the different successional stages. The "borncomplex" forest stage refers to the theoretical and alternative stage described by Donato et al. (2012). Sentences in italics inside the boxes indicate the main processes driving that successional stage

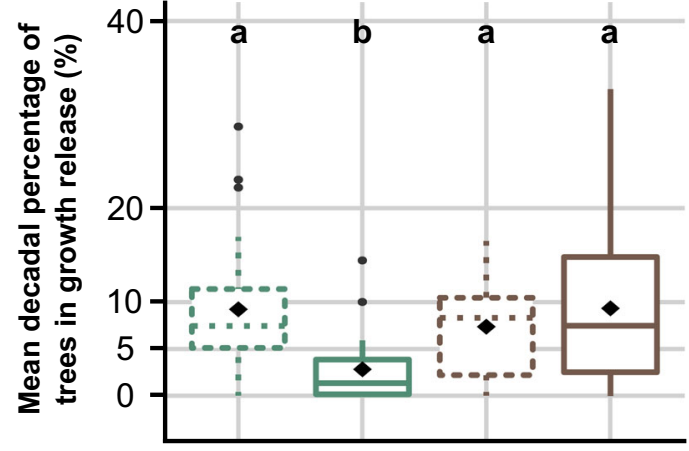

\section{Old-growth stage}

Transition old-growth True old-growth

Disturbance severity

-1.-1 Low-severity

Moderate-severity
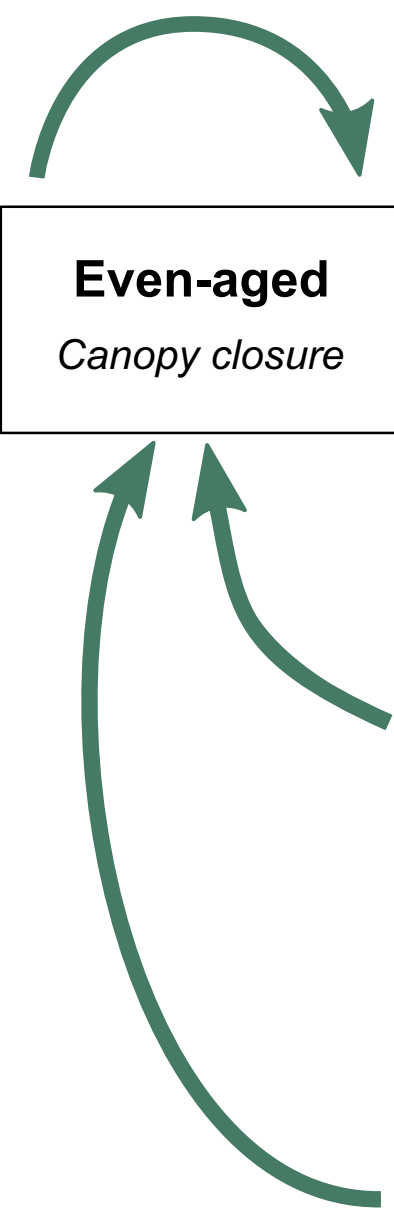

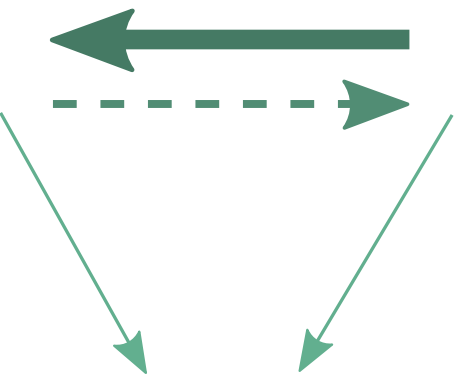

Transition old-growth

Canopy break-up

First cohort replacement

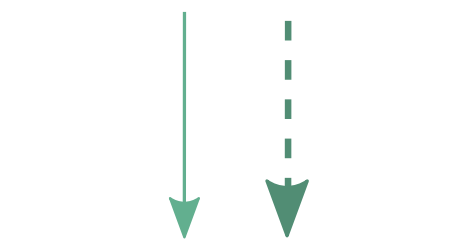

True old-growth

Gap dynamics

Patch dynamics

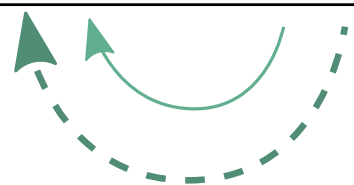

Moderate-severity disturbance

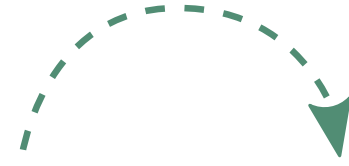

"Born complex" forest

Canopy closure

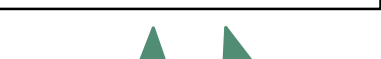

Low-severity disturbance

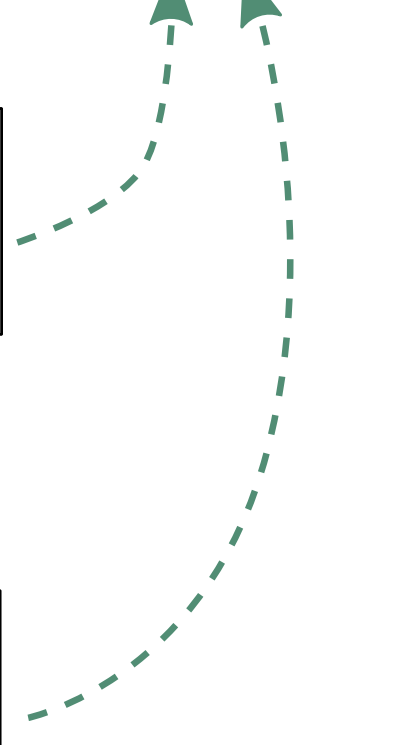

High-severity disturbance 
trees in the regeneration layer. The difference in disturbance severity between the transition (low severity) and the true oldgrowth stages (moderate severity) may be partially due to the divergence in the structural attributes of old-growth stands. Older and taller black spruce and balsam fir are more prone to windthrow than younger and smaller trees (Viereck and Johnson 1990; Robichaud and Methven 1993; Girard et al. 2014). Similarly, balsam fir is very sensitive to SBWinduced defoliation, thereby resulting in important peaks of balsam fir mortality (Kneeshaw et al. 2009; Morin et al. 2009; Garet et al. 2012). In contrast, SBW outbreak-induced mortality is generally low for black spruce (Lesieur et al. 2002; Garet et al. 2012). As such, the abundance of balsam fir often fluctuates within old-growth stands (Pham et al. 2004; De Grandpré et al. 2009). However, old-growth stands are characterized by a greater abundance of balsam fir and taller and older individual trees (Martin et al. 2018); these characteristics render them potentially more sensitive to secondary disturbances than younger stands.

The characteristics of the trees that fill the canopy openings differ based on the severity of the secondary disturbance. For both low- and moderate-severity disturbances, growth release intensity is generally minor; this pattern confirms that what we identified as disturbances of moderate severity are real and not artefacts created by a small number of major releases. Rather, the large and abrupt canopy openings favored the growth of a significant fraction of the understory. In contrast, low-severity secondary disturbances likely created only small canopy openings, favoring the growth of a small number of understory trees. In a context of a limited opening of the canopy, i.e., low-severity disturbance, the older and taller trees in the regeneration layer are more competitive than the smallest and youngest trees. In contrast, as moderate-severity disturbances affect a greater proportion of the canopy, even the smaller trees in the regeneration layer benefit from this important increase in light availability. Furthermore, the tallest trees of the regeneration layer are more likely to be killed by a moderateseverity disturbance as SBW outbreaks or windthrow events are often "top-to-down" disturbances, first killing the tallest trees and then affecting the smaller trees as disturbance severity increases (De Grandpré et al. 2018). This mortality pattern therefore favors the smallest trees. As such, the differences in disturbance severity have specific impacts on the horizontal and vertical structure of a stand as well as the subsequent stand dynamics; low-severity disturbances lead to a progressive and small-scale replacement of the killed trees by the oldest and tallest suppressed trees. In contrast, moderate-severity disturbances lead to a quick and larger-scale replacement of the killed trees, mainly by the youngest and smallest suppressed trees.

The disturbance regime within this study territory is similar to that observed by Kuuluvainen et al. (2014) and Khakimulina et al. (2016) in northern European Russia; they observed low- severity disturbances and punctual moderate-severity disturbances as a result of insect outbreaks. In both studies, lowseverity disturbances created gaps, i.e., canopy openings of $<$ $200 \mathrm{~m}^{2}$ based on McCarthy's (2001) definition, while moderate-severity disturbances created patches, i.e., canopy openings of $>200 \mathrm{~m}^{2}$ (McCarthy 2001). This combination of gap and patch dynamics is likely a common secondary disturbance regime in Fennoscandian boreal forests (McCarthy 2001; Kuuluvainen and Aakala 2011).

In our study, the size of the canopy opening resulting from each identified disturbance cannot be estimated precisely because of our methodology; it is therefore impossible to assess whether the moderate-severity disturbances effectively correspond to the creation of patches and low-severity disturbances correspond to the creation of gaps in our study stands. However, Kneeshaw and Bergeron (1998) observed a large diversity in the size of canopy openings in Quebec's boreal forests, corresponding both to gaps and patches. SBW can also create large $\left(>200 \mathrm{~m}^{2}\right)$, yet continuous, mortality areas; this creates a patchy distribution of dead and live trees in a landscape disturbed by this insect (Kneeshaw et al. 2009). Therefore, a combination of gap and patch dynamics may be a common disturbance regime in eastern Canadian boreal old-growth forests.

Our results also fall within the paradigm of a complex forest succession and disturbance regime within boreal forests. Forest succession should not be viewed as a linear pathway from structurally simple, post-primary disturbance, even-aged stands to structurally complex old stands driven by low-severity disturbances, but rather as several imbricated pathways (Kuuluvainen 2009; Reilly et al. 2015; Halpin and Lorimer 2016). Admittedly, the model describing old-growth dynamics driven solely by small-scale and low-severity disturbance remains partially valid, as some of our stands showed evidence of only low-severity disturbances over the centuries. Yet, the recurrence of moderate-severity disturbances and, more particularly, the fact that they were mainly found in true old-growth stands suggest the existence of other dynamics and succession patterns. First, the occurrence of disturbances of moderate severity in transition old-growth forests may accelerate the shift to the true old-growth stage, as a large part of the post-primary disturbance cohort is quickly killed and replaced. This may explain why moderate-severity disturbances are almost absent in the studied transition old-growth forests. Thus, the duration of the replacement of the post-primary disturbance cohort in a boreal old-growth stand may vary significantly from one stand to another. Second, once the true old-growth stage is reached, each stand may be driven by a particular secondary disturbance regime, mixing low- and moderate-severity disturbances at different proportions and producing the structural diversity observed by Martin et al. (2018). Third, disturbances of moderate severity can create young forest structures that are neither evenaged nor old growth (Donato et al. 2012; Meigs et al. 2017; Hart and Kleinman 2018). Donato et al. (2012) qualified these 
stands as "born-complex" forests, i.e., young stands exhibiting a structural complexity usually attributed to old-growth forests. Considering the importance of moderate-severity disturbances in the secondary disturbance regime, it is thus possible that the creation of born-complex forests is relatively common. Therefore, in eastern Canada, recent findings regarding the complexity of the secondary disturbance regime should encourage forest ecologists and managers to re-evaluate the dynamics and the succession of boreal forests (Fig. 5).

Discriminating low- from moderate-severity secondary disturbances by comparing tree and stand growth releases is an uncommon methodological approach. Observing the spatial patterns of tree mortality or canopy opening is a preferred method (e.g., Aakala et al. 2007; Janda et al. 2014; Khakimulina et al. 2016). In particular, it is easier to identify multiple and clustered growth releases that result, for example, from the death of a single large tree using spatialized data. This type of disturbance may challenge our definition of moderate-severity disturbances, as it could significantly change the mean stand growth. However, tree size is relatively limited in eastern Canadian boreal forests and broad-leaved species, i.e., species having the largest canopy disappear quickly during the old-growth transition (Bergeron and Harper 2009). Moderate-severity disturbances were infrequent in transition old-growth stands, i.e., stands that were the most likely to record the death of an old and large broad-leaved tree. This implies that the misclassification of disturbance severity caused by highly clustered growth releases was very unlikely. In contrast, the observed moderate-severity disturbance patterns resulted from multiple and coordinated minor understory-tree growth releases in a number of stands. Our results therefore support the hypothesis of a mixed low- and moderate-severity secondary disturbance regime in eastern Canadian boreal old-growth forests over the last centuries. Finally, a $400-\mathrm{m}^{2}$ plot surface is considered to be representative of the sampled boreal stand (MFFP 2016). Hence, we assume that disturbance dynamics observed within our plots are representative of the overall stand dynamics. Admittedly, complementary research analyzing the spatial patterns of canopy gaps and their influence on tree growth releases in the studied stands would improve our understanding of secondary disturbance dynamics in boreal old-growth forests. The use of large-scale aerial or satellite images, e.g., Kuuluvainen et al. (2014), or light detection and ranging (LiDAR) data, e.g., Vepakomma et al. (2010), offers methods to overcome the intrinsic limits of plot-scale dendrochronological analysis.

\section{Conclusion and implications for forest management}

Boreal old-growth stand dynamics generated by secondary disturbances are characterized by spatial and temporal complexity. Our study demonstrates that a given secondary disturbance regime will produce disparate severities across the landscape. This disparate pattern occurs because of a regime's inherent spatial heterogeneity and the diversity of structural characteristics of the stand subjected to the disturbance. Furthermore, two disturbances are rarely comparable, even if they share a similar nature; for example, in eastern Canada, SBW outbreaks are cyclical but differ from each other in terms of spatial distribution and severity (Morin et al. 2009; Navarro et al. 2018). Our results underline this important "complexity challenge" faced by natural disturbance-based management (Kuuluvainen 2009), as the secondary disturbance regime is a very heterogeneous process.

Martin et al. (2018) hypothesized that boreal old-growth forest structural diversity results from a combination of lowand moderate-severity disturbances. Our results support this hypothesis, highlighting the importance of disturbance heterogeneity in the creation of old-growth structural richness. In addition, such complex disturbance histories are evidence of both the strong resistance and resilience of boreal old-growth forests. Yet, recent studies have emphasized how moderateseverity disturbances can, in some cases, rejuvenate mature and old-growth stands (Donato et al. 2012; Meigs et al. 2017). Therefore, managing old-growth boreal forests requires caution and a thorough knowledge of stand characteristics to ensure their sustainable management.

To mimick low- and moderate-severity secondary disturbance requires the use of partial-cut and stem-selection harvesting. Favoring harvest practices that have varying retention levels could imitate the heterogeneity in the severity of disturbances (Hart and Kleinman 2018). By identifying temporal and severity disturbance patterns, our results can therefore serve as a basis for old-growth forest management. These proposed treatments may, however, cause post-harvest mortality and should be reserved for the most resilient old-growth structures (Girard et al. 2014; Bose et al. 2015). However, in the context of this study, it is impossible to clearly discriminate between stand structures in terms of resilience. Further research should be undertaken to better understand how the structural attributes of old-growth stands identify those stands more suitable for partial-cut or stem-selection harvests. Salvage logging in recently disturbed stands, especially after moderate-severity disturbances, can offer another solution. Exploiting naturally disturbed trees ensures that changes in the canopy structure result from natural processes. However, this type of forest intervention may have negative effects on the biodiversity, especially on saproxylic species, and thus should be used with caution (Thorn et al. 2018). Furthermore, natural secondary disturbances still occur in managed territories, and their occurrence and severity vary over time. Consequently, during periods of high natural mortality, such as during SBW outbreaks, living-tree harvesting levels should be reduced to limit pressure on the landscape. 
Acknowledgments We thank Marie-Josée Tremblay, Audrey Bédard, Alison Gagnon, Jean-Guy Girard, Émilie Chouinard, Miguel Montoro Girona, Anne-Élizabeth Harvey, Aurélie Cuvelier, and Évelyn Beliën for their help during field sampling and tree-ring analysis. Yan Boucher and Pierre Grondin from the Ministry of Forests, Wildlife and Parks (MWFP), Québec, Canada, shared their data collected from the study territory. We also thank the two anonymous reviewers who provided helpful comments that helped us to improve this manuscript.

Funding information Funding for this project was provided by the Fonds Québécois de la Recherche sur la Nature et les Technologies (FQRNT) and the Natural Sciences and Engineering Research Council of Canada (NSERC) - Université du Québec à Chicoutimi (UQAC) industrial re- search chair "Chaire de recherche industrielle du CRSNG sur la croissance de l'épinette noire et l'influence de la tordeuse des bourgeons de l'épinette sur la variabilité des paysages en zone boréale."

Data availability The datasets generated and/or analyzed during the current study are available from the corresponding author on reasonable request.

\section{Compliance with ethical standards}

Conflict of interest The authors declare that they have no conflict of interest.

\section{Appendix}

Table 3 Distribution of the sample sites per environmental type and age class

\begin{tabular}{|c|c|c|c|c|c|c|c|}
\hline \multirow[t]{2}{*}{ Potential vegetation } & \multirow[t]{2}{*}{ Slope } & \multirow[t]{2}{*}{ Deposit } & \multirow[t]{2}{*}{ Drainage } & \multicolumn{3}{|c|}{ No. sites per age class (years) } & \multirow[t]{2}{*}{ Total } \\
\hline & & & & $<100$ & $100-200$ & $<200$ & \\
\hline Balsam fir-white birch & Medium & Till & Mesic & 2 & 1 & 1 & 4 \\
\hline Black spruce-balsam fir & Medium & Till & Mesic & 1 & 1 & 3 & 5 \\
\hline Black spruce-feather moss & Low & Organic & Hydric & 1 & 1 & 1 & 3 \\
\hline Black spruce-feather moss & Low & Sand & Mesic & 1 & 1 & 1 & 3 \\
\hline Black spruce-feather moss & Low & Till & Mesic & 1 & 1 & 1 & 3 \\
\hline Black spruce-feather moss & Low & Till & Subhydric & 1 & 0 & 2 & 3 \\
\hline Total & & & & 7 & 5 & 9 & 21 \\
\hline
\end{tabular}

Table 4 Structural and environmental characteristics of the studied (A) transition old-growth and (B) true old-growth stands

\begin{tabular}{|c|c|c|c|c|c|c|c|c|c|c|}
\hline Site & Site 1 & Site 2 & Site 3 & Site 4 & Site 5 & Site 6 & Site 7 & Site 8 & Site 9 & Site 10 \\
\hline Cohort basal area proportion & 0 & 0.54 & 0.98 & 0 & 0.12 & 0.12 & 0 & 0 & 0.15 & 0.83 \\
\hline Weibull's shape parameter & 1.26 & 1.44 & 2.75 & 1.38 & 0.74 & 1.19 & 0.69 & 1.29 & 1.05 & 2.67 \\
\hline Min. time since last fire (years) & 86 & 219 & 206 & 195 & 184 & 193 & 89 & 89 & 218 & 286 \\
\hline Tree density $\left(n \cdot h^{-1}\right)$ & 1100 & 1250 & 1275 & 1875 & 950 & 1025 & 1575 & 50 & 450 & 1325 \\
\hline Sapling density $\left(n \cdot \mathrm{ha}^{-1}\right)$ & 1100 & 1050 & 275 & 2400 & 1125 & 1200 & 3200 & 4050 & 1225 & 650 \\
\hline Basal area $\left(\mathrm{m}^{2} \cdot \mathrm{ha}^{-1}\right)$ & 30.63 & 25.19 & 35.45 & 21.75 & 20.13 & 14.52 & 29.73 & 0.36 & 5.52 & 20.57 \\
\hline Maximum height (m) & 13.4 & 20.3 & 19.4 & 14.4 & 19.1 & 16.2 & 16.7 & 7.9 & 13.9 & 17.5 \\
\hline Slope $(\%)$ & 35 & 8 & 3 & 0 & 10 & 7 & 5 & 0 & 0 & 27 \\
\hline Depth of the organic horizon $(\mathrm{cm})$ & 12 & 39 & 40 & 16 & 40 & 45 & 13 & 65 & 38 & 25 \\
\hline \multicolumn{11}{|l|}{ B } \\
\hline Site & Site 11 & Site 12 & Site 13 & Site 14 & Site 15 & Site 16 & Site 17 & Site 18 & Site 19 & Site 20 \\
\hline Cohort basal area proportion & 0.92 & 1 & 0.86 & 0.75 & 0.83 & 0.85 & 0.92 & 0.93 & 0.63 & 0.65 \\
\hline Weibull's shape parameter & 0.97 & 0.72 & 1.14 & 0.89 & 0.69 & 0.76 & 0.97 & 0.89 & 0.9 & 0.73 \\
\hline Min. time since last fire (years) & 189 & 263 & 281 & 256 & 277 & 279 & 283 & 266 & 193 & 238 \\
\hline Tree density $\left(n \cdot \mathrm{ha}^{-1}\right)$ & 975 & 675 & 675 & 500 & 1125 & 950 & 850 & 700 & 850 & 600 \\
\hline Sapling density $\left(n \cdot \mathrm{ha}^{-1}\right)$ & 8550 & 1750 & 2150 & 1800 & 2525 & 3650 & 2800 & 1175 & 2250 & 2750 \\
\hline Basal area $\left(\mathrm{m}^{2} \cdot \mathrm{ha}^{-1}\right)$ & 15.18 & 18.48 & 6.84 & 7.1 & 28.29 & 12.67 & 17.68 & 14.27 & 16.09 & 20.7 \\
\hline Maximum height (m) & 17.7 & 22.6 & 16.9 & 15.8 & 21.2 & 17.8 & 23.4 & 19.4 & 21.5 & 21.6 \\
\hline Slope $(\%)$ & 18 & 19 & 0 & 0 & 18 & 2 & 26 & 5 & 7 & 22 \\
\hline Depth of the organic horizon $(\mathrm{cm})$ & 45 & 17 & 34 & 20 & 31 & 50 & 43 & 15 & 20 & 14 \\
\hline
\end{tabular}


Table 5 Number of trees sampled and year (CE) by which at least 10 trees were sampled by species in the studied (A) transition old-growth and (B) true old-growth stands

\begin{tabular}{|c|c|c|c|c|c|c|c|c|c|c|c|}
\hline \multicolumn{12}{|l|}{ A } \\
\hline Parameter & Species & Site 1 & Site 2 & Site 3 & Site 4 & Site 5 & Site 6 & Site 7 & Site 8 & Site 9 & Site 10 \\
\hline \multirow[t]{2}{*}{ No. of trees sampled } & Black spruce & 15 & 33 & 50 & 40 & 37 & 37 & 44 & 43 & 18 & 20 \\
\hline & Balsam fir & 3 & 0 & 12 & 0 & 0 & 0 & 0 & 0 & 0 & 3 \\
\hline \multirow[t]{2}{*}{ Year by which $n$ trees $\geq 10$} & Black spruce & 1939 & 1820 & 1938 & 1899 & 1854 & 1910 & 1840 & 1875 & 1811 & 1832 \\
\hline & Balsam fir & - & - & 1907 & - & - & - & - & - & - & - \\
\hline \multicolumn{12}{|l|}{ B } \\
\hline Parameter & Species & Site 11 & Site 12 & Site 13 & Site 14 & Site 15 & Site 16 & Site 17 & Site 18 & Site 19 & Site 20 \\
\hline \multirow[t]{2}{*}{ No. of trees sampled } & Black spruce & 24 & 26 & 30 & 15 & 23 & 34 & 37 & 37 & 36 & 10 \\
\hline & Balsam fir & 16 & 15 & 0 & 0 & 29 & 0 & 8 & 2 & 13 & 13 \\
\hline \multirow[t]{2}{*}{ Year by which $n$ trees $\geq 10$} & Black spruce & 1929 & 1872 & 1935 & 1808 & 1824 & 1876 & 1806 & 1894 & 1825 & 1837 \\
\hline & Balsam fir & 1939 & 1920 & - & - & 1869 & - & - & - & 1925 & 1892 \\
\hline
\end{tabular}

Table 6 Contingency table of the age and diameter of trees at the release times within the studied chronologies

\begin{tabular}{llllll}
\hline Diameter at release (cm) & \multicolumn{2}{l}{ Age at release (years) } & \multirow{2}{*}{ Total } \\
\cline { 2 - 5 } & \multicolumn{2}{l}{$\begin{array}{l}50- \\
\end{array}$} & & $100-$ & $>150$ \\
& 100 & 150 & & \\
\hline$<10$ & 473 & 552 & 239 & 51 & 1315 \\
& $36 \%$ & $42 \%$ & $18.2 \%$ & $3.9 \%$ & $100 \%$ \\
\multirow{2}{*}{ Total } & 4 & 84 & 121 & 89 & 298 \\
& $1.3 \%$ & $28.2 \%$ & $40.6 \%$ & $29.9 \%$ & $100 \%$ \\
& 477 & 636 & 360 & 140 & 1613 \\
& $29.6 \%$ & $39.4 \%$ & $22.3 \%$ & $8.7 \%$ & $100 \%$
\end{tabular}

$\chi^{2}=354.016, d f=3$, Cramer's $V=0.468, p<0.001$

\section{References}

[MFFP] Ministère de la Forêt de la faune et des Parcs. 2016. Norme d'inventaire écoforestier. Placettes-échantillons temporaires. Québec: Direction des Inventaires Forestiers, Ministère de la Forêt, de la Faune et des Parcs.

Aakala T, Kuuluvainen T, De Grandpré L, Gauthier S (2007) Trees dying standing in the northeastern boreal old-growth forests of Quebec : spatial patterns, rates, and temporal variation. Can J For Res 61:50 61. https://doi.org/10.1139/X06-201

Bailey RL, Dell R (1973) Quantifying diameter distributions with the Weibull function. For Sci 19(2):97-104

Basham JT. 1991. Stem decay in living trees in Ontario's forests: a user's compendium and guide.

Bergeron Y, Charron D (1994) Postfire stand dynamics in a southern boreal forest (Québec): a dendroecological approach. Écoscience. 1:173-184. https://doi.org/10.1080/11956860.1994.11682241

Bergeron Y, Cyr D, Drever CR, Flannigan M, Gauthier S, Kneeshaw D, Lauzon È, Leduc A, Le Goff H, Lesieur D et al (2006) Past, current, and future fire frequencies in Quebec's commercial forests: implications for the cumulative effects of harvesting and fire on age-class structure and natural disturbance-based management. Can J For Res 36:2737-2744. https://doi.org/10.1139/x06-177

Bergeron Y, Gauthier S, Kafka V, Lefort P, Lesieur D (2001) Natural fire frequency for the eastern Canadian boreal forest: consequences for sustainable forestry. Can J For Res 31:384-391. https://doi.org/10. 1139/cjfr-31-3-384

Bergeron Y, Harper KA (2009) Old-growth forests in the Canadian boreal: the exception rather than the rule? In: Wirth $\mathrm{C}$, Gleixner $\mathrm{G}$, Heimann M, editors. Old-growth forests: function, fate and value. ecological studies. New York: Springer. p. 285-300.

Bergeron Y, Leduc A, Harvey BD, Gauthier S (2002) Natural fire regime: a guide for sustainable management of the Canadian boreal forest. Silva Fenn 36:81-95

Bose AK, Harvey BD, Brais S (2015) Does partial harvesting promote old-growth attributes of boreal mixedwood trembling aspen (Populus tremuloides Michx.) stands? For Ecol Manag 353:173186. https://doi.org/10.1016/j.foreco.2015.05.024

Bouchard M, Kneeshaw D, Bergeron Y (2006) Forest dynamics after successive spruce budworm outbreaks in mixedwood forests. Ecology. 87:2319-2329. https://doi.org/10.1890/0012-9658(2006) 87[2319:FDASSB]2.0.CO;2

Bouchard M, Pothier D (2011) Long-term influence of fire and harvesting on boreal forest age structure and forest composition in eastern Québec. For Ecol Manag 261:811-820. https://doi.org/10.1016/j. foreco.2010.11.020

Boucher Y, Perrault-Hébert M, Fournier R, Drapeau P, Auger I (2017) Cumulative patterns of logging and fire (1940-2009): consequences on the structure of the eastern Canadian boreal forest. Landsc Ecol 32:361-375. https://doi.org/10.1007/s10980-016-0448-9

Boudreault C, Paquette M, Fenton NJ, Pothier D, Bergeron Y (2018) Changes in bryophytes assemblages along a chronosequence in eastern boreal forest of Quebec. Can J For Res 48:821-834. https://doi. org/10.1139/cjfr-2017-0352

Cooke BJ, Lorenzetti F (2006) The dynamics of forest tent caterpillar outbreaks in Québec. Canada For Ecol Manage 226:110-121. https://doi.org/10.1016/j.foreco.2006.01.034

Cumming SG, Schmiegelow FKA, Burton PJ (2000) Gap dynamics in boreal aspen stands : is the forest older than we think? Ecol Appl 10: 744-759

Donato DC, Campbell JL, Franklin JF (2012) Multiple successional pathways and precocity in forest development: can some forests be born complex? J Veg Sci 23:576-584. https://doi.org/10.1111/j.16541103.2011.01362.x

Doucet R, Boily J. 1995. Note de rechercher forestière $n^{\circ}$ 68: Croissance en hauteur de régénération d'Épinette noire et de Sapin baumier après la coupe. (68):4. Ministère des Ressources Naturelles du Québec.

Fall A, Fortin M-J, Kneeshaw DD, Yamasaki SH, Messier C, Bouthillier L, Smyth C (2004) Consequences of various landscape-scale 
ecosystem management strategies and fire cycles on age-class structure and harvest in boreal forests. Can J For Res 34:310-322. https:// doi.org/10.1139/x03-143

Fenton NJ, Bergeron Y (2008) Does time or habitat make old-growth forests species rich? Bryophyte richness in boreal Picea mariana forests. Biol Conserv 141:1389-1399. https://doi.org/10.1016/j. biocon.2008.03.019

Fraver S, White AS (2005) Identifying growth releases in dendrochronological studies of forest disturbance. Can J For Res 35:1648-1656. https://doi.org/10.1139/x05-092

Garet J, Pothier D, Bouchard M (2009) Predicting the long-term yield trajectory of black spruce stands using time since fire. For Ecol Manag 257: 2189-2197. https://doi.org/10.1016/j.foreco.2009.03.001

Garet J, Raulier F, Pothier D, Cumming SG (2012) Forest age class structures as indicators of sustainability in boreal forest: are we measuring them correctly? Ecol Indic 23:202-210. https://doi.org/ 10.1016/j.ecolind.2012.03.032

Gauthier S, Boucher D, Morissette J, De Grandpré L (2010) Fifty-seven years of composition change in the eastern boreal forest of Canada. J Veg Sci 21:772-785. https://doi.org/10.1111/j.1654-1103.2010. 01186.x

Girard F, De Grandpré L, Ruel JC (2014) Partial windthrow as a driving process of forest dynamics in old-growth boreal forests. Can J For Res 44:1165-1176. https://doi.org/10.1139/cjfr-2013-0224

De Grandpré L, Gauthier S, Allain C, Cyr D, Périgon S, Pham AT, Boucher D, Morissette J, Reyes G, Aakala T et al (2009) Towards an ecosystem approach to managing the boreal forest in the North Shore Region: disturbance regime and natural forest dynamics. In: Gauthier S, Vaillancourt M-A, Leduc A, De Grandpré L, Kneeshaw DD, Morin H, Drapeau P, Bergeron Y (eds) Ecosystem management in the boreal forest. Les Presses de l'Université du Québec, Québec, pp 229-255

De Grandpré L, Waldron K, Bouchard M, Gauthier S, Beaudet M, Ruel JC, Hébert C, Kneeshaw DD (2018) Incorporating insect and wind disturbances in a natural disturbance-based management framework for the boreal forest. Forests. 9:1-20. https://doi.org/10.3390/ f9080471

Gray DR (2008) The relationship between climate and outbreak characteristics of the spruce budworm in eastern Canada. Clim Chang 87: 361-383. https://doi.org/10.1007/s10584-007-9317-5

Halpin CR, Lorimer CG (2016) Trajectories and resilience of stand structure in response to variable disturbance severities in northern hardwoods. For Ecol Manag 365:69-82. https://doi.org/10.1016/j. foreco.2016.01.016

Harper KA, Bergeron Y, Drapeau P, Gauthier S, De Grandpré L (2005) Structural development following fire in black spruce boreal forest. For Ecol Manag 206:293-306. https://doi.org/10.1016/j.foreco. 2004.11.008

Hart JL, Kleinman JS (2018) What are intermediate-severity forest disturbances and why are they important? Forests 9. https://doi.org/10. 3390/f9090579

Holmes R (1983) Computer-assisted quality control in tree-ring dating measurement. Tree-Ring Bull 43:69-78

Jan W, Volney A (1988) Analysis of historic jack pine budworm outbreaks in the Prairie provinces of Canada. Can J For Res 18:11521158

Janda P, Svoboda M, Bače R, Čada V, Peck JLE (2014) Three hundred years of spatio-temporal development in a primary mountain Norway spruce stand in the Bohemian Forest, central Europe. For Ecol Manag 330: 304-311. https://doi.org/10.1016/j.foreco.2014.06.041

Kerharo L (2013) Dynamique des chablis dans les pessières de la ceinture d'argile. Mémoire de maîtrise. Université du Québec à Montréal, $152 \mathrm{p}$
Khakimulina T, Fraver S, Drobyshev I (2016) Mixed-severity natural disturbance regime dominates in an old-growth Norway spruce forest of northwest Russia. J Veg Sci 27:400-413. https://doi.org/10. 1111/jvs. 12351

Kneeshaw D, Bergeron Y, Kuuluvainen T (2011) Forest ecosystem structure and disturbance dynamics across the circumboreal forest. In: Millington AC (ed) Handbook of biogeography. Sage, London, pp 261-278

Kneeshaw D, Gauthier S (2003) Old growth in the boreal forest: a dynamic perspective at the stand and landscape level. Environ Rev 11: S99-S114. https://doi.org/10.1139/a03-010

Kneeshaw DD, Bergeron Y (1998) Canopy gap characteristics and tree replacement in the southeastern boreal forest. Ecology. 79:783-794

Kneeshaw DD, Lauzon È, De Römer A, Reyes G, Belle-Isle J, Messier J, Gauthier S (2009) Appliquer les connaissances sur les régimes de perturbations naturelles pour développer une foresterie qui s'inspire de la nature dans le sud de la péninsule gaspésienne. In: Gauthier $\mathrm{S}$, Vaillancourt M-A, Leduc A, De Grandpré L, Kneeshaw DD, Morin H, Drapeau P, Bergeron Y (eds) Ecosystem management in the boreal forest. Presses de l'Université du Québec, Québec, pp 215240

Krause C (1997) The use of dendrochronological material from buildings to get information about past spruce budworm outbreaks. Canada $\mathrm{J}$ For Res 27:69-75

Kuuluvainen T (2002) Natural variability of forests as a reference for restoring and managing biological diversity in boreal Fennoscandia. Silva Fenn 36:97-125. https://doi.org/10.1579/08A-490.1

Kuuluvainen T (2009) Forest management and biodiversity conservation based on natural ecosystem dynamics in northern Europe : the complexity challenge. Ambio. 38:309-315

Kuuluvainen T, Aakala T. 2011. Natural forest dynamics in boreal fennoscandia: a review and classification. Silva Fenn. 45:823841. doi:10.14214/sf.73.

Kuuluvainen T, Wallenius TH, Kauhanen H, Aakala T, Mikkola K, Demidova N, Ogibin B (2014) Episodic, patchy disturbances characterize an old-growth Picea abies dominated forest landscape in northeastern Europe. For Ecol Manag 320:96-103. https://doi.org/ 10.1016/j.foreco.2014.02.024

Laberge M-J, Payette S, Bousquet J (2000) Life span and biomass allocation of stunted black spruce clones in the subarctic environment. J Ecol 88:584-593

Larson DW (2001) The paradox of great longevity in a short-lived tree species. Exp Gerontol 36:651-673

Lecomte N, Simard M, Bergeron Y (2006) Effects of fire severity and initial tree composition on stand structural development in the coniferous boreal forest of northwestern Québec. Canada Ecoscience 13:152-163. https://doi.org/10.2980/11195-6860-13-2-152.1

Lesieur D, Gauthier S, Bergeron Y (2002) Fire frequency and vegetation dynamics for the south-central boreal forest of Quebec. Canada Can J For Res 32:1996-2009. https://doi.org/10.1139/x02-113

MacLean DA, Andersen AR (2008) Impact of a spruce budworm outbreak in balsam fir and subsequent stand development over a 40 -year period. For Chron 84:60-69. https://doi.org/10.5558/tfc84060-1

Martin M, Fenton NJ, Morin H (2018) Structural diversity and dynamics of boreal old-growth forests case study in Eastern Canada. For Ecol Manag 422:125-136. https://doi.org/10.1016/j.foreco.2018.04.007

McCarthy J (2001) Gap dynamics of forest trees: a review with particular attention to boreal forests. Environ Rev 9:1-59. https://doi.org/10. 1139/a00-012

McCarthy JW, Weetman G (2006) Age and size structure of gap-dynamic, old-growth boreal forest stands in Newfoundland. Silva Fenn 40: 209-230 
Meigs GW, Morrissey RC, Bače R, Chaskovskyy O, Čada V, Després T, Donato DC, Janda P, Lábusová J, Seedre M et al (2017) More ways than one: mixed-severity disturbance regimes foster structural complexity via multiple developmental pathways. For Ecol Manag 406: 410-426. https://doi.org/10.1016/j.foreco.2017.07.051

Messier C, Doucet R, Ruel J-C, Claveau Y, Kelly C, Lechowicz MJ (1999) Functional ecology of advance regeneration in relation to light in boreal forests. Can J For Res 29:812-823. https://doi.org/ 10.1139/cjfr-29-6-812

Montoro Girona M, Lussier J-M, Morin H, Thiffault N (2018) Conifer regeneration after experimental shelterwood and seed-tree treatments in boreal forests: finding silvicultural alternatives. Front Plant Sci 9:1-14. https://doi.org/10.3389/fpls.2018.01145

Morin H, Laprise D (1990) Histoire récente des épidémies de la Tordeuse des bourgeons de l'épinette au nord du lac Saint-Jean (Québec) : une analyse dendrochronologique. Can J For Res 20:1-8.

Morin H, Laprise D, Simon AA, Amouch S (2009) Spruce budworm outbreak regimes in in eastern North America. In: Gauthier $\mathrm{S}$, Vaillancourt M-A, Leduc A, De Grandpré L, Kneeshaw DD, Morin H, Drapeau P, Bergeron Y (eds) Ecosystem management in the boreal forest. Les Presses de l'Université du Québec, Québec, pp $156-182$

Navarro L, Morin H, Bergeron Y, Montoro GM (2018) Changes in spatiotemporal patterns of 20th century spruce budworm outbreaks in eastern Canadian boreal forests. Front Plant Sci 9:1905. https://doi. org/10.3389/FPLS.2018.01905

Nealis VG, Lomic PV (1994) Host-plant influence on the population ecology of the jack pine budworm, Choristoneura pinus (Lepidoptera: Tortricidae). Ecol Entomol 19:367-373. https://doi. org/10.1111/j.1365-2311.1994.tb00254.x

Nowacki GJ, Abrams MD (1997) Radial-growth averaging criteria for reconstructing disturbance histories from presettlement-origin oaks. Ecol Monogr 67:225-249

Östlund L, Zackrisson O, Axelsson A-L (1997) The history and transformation of a Scandinavian boreal forest landscape since the 19th century. Can J For Res 27:1198-1206. https://doi.org/10.1139/x97070

Perry DA, Amaranthus MP (1997) Disturbance, recovery and stability. In: Creating a forestry for the 21 st century. The science of ecosystem management. Washington D.C.: Island Press. p. 31-56.

Pham AT, De Grandpré L, Gauthier S, Bergeron Y (2004) Gap dynamics and replacement patterns in gaps of the northeastern boreal forest of Quebec. Can J For Res 34:353-364. https://doi.org/10.1139/x03265

Pollock SL, Payette S (2010) Stability in the patterns of long-term development and growth of the Canadian spruce-moss forest. J Biogeogr 37:1684-1697. https://doi.org/10.1111/j.1365-2699.2010.02332.x

R Core Team (2016) R: a language and environment for statistical computing. R Foundation for Statistical Computing, Vienna. URL http:// www.R-project.org/.

Reilly MJ, Spies TA, Peters DPC (2015) Regional variation in stand structure and development in forests of Oregon, Washington, and inland Northern California. Ecosphere. 6:1-27. https://doi.org/10. 1890/ES14-00469.1

Reyes GP, Kneeshaw D (2008) Moderate-severity disturbance dynamics in Abies balsamea-Betula spp. forests: the relative importance of disturbance type and local stand and site characteristics on woody vegetation response. Écoscience. 15:241-249. https://doi.org/10. 2980/15-2-3082

Robichaud E, Methven IR (1993) The effect of site quality on the timing of stand breakup, tree longevity, and the maximum attainable height of black spruce. Can J For Res 23:1514-1519
Robitaille A, Saucier J-P (1998) Paysages régionaux du Québec méridional. Les Publications du Québec, Montréal

Rossi S, Tremblay MJ, Morin H, Savard G (2009) Growth and productivity of black spruce in even- and uneven-aged stands at the limit of the closed boreal forest. For Ecol Manag 258:2153-2161. https:// doi.org/10.1016/j.foreco.2009.08.023

Ruel J (2000) Factors influencing windthrow in balsam fir forests : from landscape studies to individual tree studies. For Ecol Manag 135: $169-178$

Shorohova E, Kneeshaw D, Kuuluvainen T, Gauthier S (2011) Variability and dynamics of old-growth forests in the circumboreal zone: implications for conservation, restoration and management. Silva Fenn 45:785-806

Signorell A. 2017. DescTools: tools for descriptive statistics. R package version 0.99.28

Siitonen J. (2001) Forest management, coarse woody debris and saproxylic organisms : Fennoscandian boreal forests as an example. Ecol Bull. : 10-41.

Sing T, Sander O, Beerenwinkel N, Lengauer T (2005) ROCR: visualizing classifier performance in R. Bioinformatics. 21:78881

Smirnova E, Bergeron Y, Brais S (2008) Influence of fire intensity on structure and composition of jack pine stands in the boreal forest of Quebec: live trees, understory vegetation and dead wood dynamics. For Ecol Manag 255:2916-2927. https://doi.org/10.1016/j.foreco. 2008.01.071

Szewczyk J, Szwagrzyk J, Muter E (2011) Tree growth and disturbance dynamics in old-growth subalpine spruce forests of the Western Carpathians. Can J For Res 41:938-944. https://doi.org/10.1139/ x11-029

Thorn S, Bässler C, Brandl R, Burton PJ, Cahall R, Campbell JL, Castro J, Choi CY, Cobb T, Donato DC et al (2018) Impacts of salvage logging on biodiversity: a meta-analysis. J Appl Ecol 55:279-289. https://doi.org/10.1111/1365-2664.12945

Tjur T (2009) Coefficients of determination in logistic regression models - a new proposal: the coefficient of discrimination. Am Stat 63:366-372. https://doi.org/10.1198/tast.2009.08210

Trexler JC, Travis J (1993) Nontraditional regression analyses. Ecology. 74:1629-1637

Tremblay M-J, Rossi S, Morin H, (2011) Growth dynamics of black spruce in stands located between the 51st and 52nd parallels in the boreal forest of Quebec, Canada. Canadian Journal of Forest Research 41(9): 1769-1778

Uhlig PA, Harris G, Craig C, Bowling B, Chambers B, Naylor B, Beemer G (2001) Old-growth forest definitions for Ontario. In: Ontario Ministry of Natural Resources, editor. Ontario, Queen's Printer for

Vanha-Majamaa I, Lilja S, Ryömä R, Kotiaho JS, Laaka-Lindberg S, Lindberg H, Puttonen P, Tamminen P, Toivanen T, Kuuluvainen T (2007) Rehabilitating boreal forest structure and species composition in Finland through logging, dead wood creation and fire: the EVO experiment. For Ecol Manag 250:77-88. https://doi.org/10. 1016/j.foreco.2007.03.012

Vepakomma U, Kneeshaw D, St-Onge B (2010) Interactions of multiple disturbances in shaping boreal forest dynamics: a spatially explicit analysis using multi-temporal lidar data and high-resolution imagery. J Ecol 98:526-539. https://doi.org/10.1111/j.1365-2745.2010. 01643.x

Viereck LA, Johnson WF (1990) Picea mariana (Mill) B.S.P.—black spruce. In: Service USDAF (ed) Silvics of North America. 1, Conifers, vol 2. Hardwood, Washington D.C, pp 227-237

Waldron K, Ruel JC, Gauthier S (2013) The effects of site characteristics on the landscape-level windthrow regime in the North Shore region of Quebec. Canada Forestry 86:159-171. https://doi.org/10.1093/ forestry/cps061 
Ward C, Pothier D, Pare D (2014) Do boreal forests need fire disturbance to maintain productivity ? Ecosystems. 17:1053-1067. https://doi. org/10.1007/s10021-014-9782-4

Wickham H. (2016) ggplot2: elegant graphics for data analysis.

Wirth C, Lichstein JW (2009) The imprint of species turnover on oldgrowth forest carbon balances - insights from a trait-based model of forest dynamics. In: Wirth C, Gleixner G, Heimann M, editors. Oldgrowth forests: function, fate and value. Ecological Studies. Berlin: Springer. p. 81-114.

Worrall JJ, Lee TD, Harrington TC (2005) Forest dynamics and agents that initiate and expand canopy gaps in Picea-Abies forests of
Crawford Notch, New Hampshire. USA J Ecol 93:178-190. https://doi.org/10.1111/j.1365-2745.2004.00937.x

Zweig MH, Campbell G (1993) Receiver-operating characteristic (ROC) plots: a fundamental evaluation tool in clinical medicine. Clin Chem 39:561-577

Publisher's note Springer Nature remains neutral with regard to jurisdictional claims in published maps and institutional affiliations. 